\title{
Deanery placement and the Situational Judgement Test
}

This article was published in the following Dove Press journal:

Advances in Medical Education and Practice

23 November 2015

Number of times this article has been viewed

\section{Mycroft J Halliwell-Ewen' \\ Charlotte Lee ${ }^{2}$ \\ Dipesh P Gopal ${ }^{3}$}

'Department of Medicine, University of Cambridge School of Clinical Medicine, Cambridge, UK ${ }^{2}$ Moorfields Eye Hospital, London, UK ${ }^{3}$ Department of Stroke Medicine, Royal Free Hospital, London, UK

Correspondence: Dipesh P Gopal 6th floor, Department of Stroke Medicine, Royal Free Hospital, Pond Street, London NW3 2QG, UK Email dipeshgopal@doctors.org.uk

\section{Dear editor}

Singagireson et al ${ }^{1}$ explored the contentious issue of allocating Foundation Programme posts using the Situational Judgement Test (SJT), a system that has been criticized on the basis of fairness. ${ }^{2,3}$ The authors found evidence ${ }^{4}$ that suggested academic performance at medical school did not correlate with SJT scores, and suggested that relative success on the SJT could artificially inflate academic scores attained at medical school. They concluded that the SJT was a fair means of assessing other skills required in the role of a physician. Whilst we are in agreement, the argument they present fails to examine the reasoning behind using the SJT.

The reliability of SJTs in general is fairly good, ${ }^{5-7}$ and it is a system used in general practice national training allocation in the UK and abroad. ${ }^{8}$ However, the statement "logic suggests if you have done well throughout medical school, you would have gained the knowledge and aptitude to perform well in the SJT" is a straw-man argument. The evidence the authors use to refute this did not show a statistically significant correlation between academic performance and SJT score. The data set was limited by its sample size $(\mathrm{n}=239)$, and there was risk of selection bias with inclusion of data from $36 \%$ of all UK medical schools $(n=12)$, in addition to reporting bias. ${ }^{4}$ However, this is irrelevant, as the SJT is not something you can revise for. Indeed, the SJT does not require aptitude or knowledge, nor should it be expected to assess academic rigor. It is an interdisciplinary psychometric test used to assess a candidate's behavioral tendencies in different workplace situations. Within this context, it tests commitment to professionalism, coping under pressure, effective communication, patient focus, and effective teamwork. ${ }^{9}$ These are skills that form gradually, and cannot be learned from a textbook. Becoming a good doctor goes beyond academic rating.

Moreover, in stark contrast to their claim that an "off day" during the SJT would detrimentally affect deanery allocation, statistics from this year identified that $90.5 \%$ of medical students were allocated one of their top five deanery choices $(n=8119) .{ }^{10}$ They also postulated on the "selective advantage" when an academically gifted student enrolls at a less competitive university, altogether insinuating that somehow medical school applicants strategically calculate which university to attend on the basis of academic competition. One would imagine that according to their article, the SJT would have a large spread in scores to be able to mitigate for the variability in academic ranking. This year, average SJT scores were between 37.4 and 40.9 (out of 50) in UK medical schools. This is less than a $9 \%$ variation; significant, but not sweeping. ${ }^{10}$ 
Finally, we would like to call into question the importance of there being interuniversity variability in quality of graduates. Perhaps the authors were alluding to the degree of preparedness a medical student felt in being able to practise confidently as a Foundation Year 1 (F1) doctor. A report compiled by the regulating authority, the General Medical Council (GMC), stated that overall medical graduates are good F1s, despite wide variation in the proportion of medical students feeling prepared for Foundation practice. ${ }^{11}$ The GMC looked at past research ${ }^{12}$ and commissioned a rapid review by Monrouxe et al. ${ }^{13}$ Preparedness among newly qualified F1s is improving: 70\% felt prepared for their new posts in 2014 compared to $51 \%$ in 2012 . Changes in question wording could have been a factor in this; however, graduate preparedness has been steadily increasing since 2009. ${ }^{11}$ More importantly, the number of doctors in difficulty has declined from $4.6 \%$ in 2010 to $2.6 \%$ in 2013 for F1s. ${ }^{11}$

Daily working life requires interpersonal skills and emotional durability that ought to be assessed. Greater engagement from medical students in the realities of ward work can be a challenge, and any pressure to shift the focus away from theoretical knowledge is welcome. The context-dependent syllabus of the SJT could incentivize students to spend time shadowing on the wards. Medicine is a vocation; preparedness or quality of F1s is dependent on experience. Surely the goal of the SJT is to motivate better comprehension of the GMC Code of Conduct through application, not study.

\section{Disclosure}

The authors report no conflicts of interest in this communication.

\section{References}

1. Singagireson S, Ramjeeawon N, Ravindra S, Shah N, Singh B. Is it fair for a junior doctor's deanery to be largely based on one test: a student's perspective. Adv Med Educ Pract. 2015;6:499-500.
2. Sharma N. Is the UK's situational judgement test a fair and appropriate way to allocate jobs to new doctors? Educ Health (Abingdon). 2015; 27(1):66

3. Patel AB, Norris JM. Situational judgement tests for medical students: really the best way to determine your future? Med Teach. 2012; 34(9):777.

4. Simon E, Walsh K, Paterson-Brown F, Cahill D. Does a high ranking mean success in the situational judgement test? Clin Teach. 2015; 12(1):42-45.

5. Patterson F, Ashworth V, Zibarras L, Coan P, Kerrin M, O'Neill P. Evaluations of situational judgement tests to assess non-academic attributes in selection. Med Educ. 2012;46(9):850-868.

6. Patterson F, Prescott-Clements L, Zibarras L, Edwards H, Kerrin M, Cousans F. Recruiting for values in healthcare: a preliminary review of the evidence. Adv Health Sci Educ Theory Pract. Epub 2015 Jan 25.

7. Lievens F. Adjusting medical school admission: assessing interpersonal skills using situational judgement tests. Med Educ. 2013;47(2): 182-189.

8. Luschin-Ebengreuth M, Dimai HP, Ithaler D, Neges HM, Reibnegger G. Situational judgment test as an additional tool in a medical admission test: an observational investigation. BMC Res Notes. 2015;8:81.

9. Patterson F, Ashworth V, Good D. Situational Judgement Tests: A Guide for Applicants to the UK Foundation Programme. 2nd ed. London: Medical Schools Council; 2013. Available from: http:// www.foundationprogramme.nhs.uk/download.asp?file=Situational_ Judgement_Tests_Monograph_FINAL_August_2013-1.pdf. Accessed September 12, 2015.

10. UK Foundation Programme Office. Foundation Programme 2015 recruitment stats and facts: interim report - 20 April 2015. Available from: http://www.foundationprogramme.nhs.uk/download. asp?file=Stats_and_facts_FP2015_interim_report_-_22_April_2015_ FINAL.pdf. Accessed September 12, 2015.

11. General Medical Council. Be Prepared: Are New Doctors Safe to Practise? Manchester: General Medical Council; 2014. Available from: http://www.gmc-uk.org/Be_prepared_are_new_doctors_safe_to_ practise_Oct_2014.pdf_58044232.pdf. Accessed September 12, 2015.

12. Goldacre MJ, Lambert TW, Svirko E. Foundation doctors' views on whether their medical school prepared them well for work: UK graduates of 2008 and 2009. Postgrad Med J. 2014;90(1060):63-68.

13. Monrouxe L, Bullock A, Cole J, et al. How prepared are UK medical graduates for practice? Final report from a programme of research commissioned by the General Medical Council. 2014. Available from: http://www.gmc-uk.org/How_Prepared_are_UK_Medical_Graduates_ for_Practice_SUBMITTED_Revised_140614.pdf_58034815.pdf. Accessed September 23, 2015.

Dove Medical Press encourages responsible, free and frank academic debate. The content of the Advances in Medical Education and Practice 'letters to the editor' section does not necessarily
represent the views of Dove Medical Press, its officers, agents, employees, related entities or the Advances in Medical Education and Practice editors. While all reasonable steps have been taken to represent the views of Dove Medical Press, its officers, agents, employees, related entities or the Advances in Medical Education and Practice editors. While all reasonable steps have been taken to
confirm the content of each letter, Dove Medical Press accepts no liability in respect of the content of any letter, nor is it responsible for the content and accuracy of any letter to the editor.

Advances in Medical Education and Practice

Dovepress

\section{Publish your work in this journal}

Advances in Medical Education and Practice is an international, peerreviewed, open access journal that aims to present and publish research on Medical Education covering medical, dental, nursing and allied health care professional education. The journal covers undergraduate education, postgraduate training and continuing medical education including emerging trends and innovative models linking education, research, and health care services. The manuscript management system is completely online and includes a very quick and fair peer-review system. Visit http://www.dovepress.com/testimonials.php to read real quotes from published authors. 